\title{
NOTES.
}

\section{NOTE ON THE OCCURRENCE OF SEQUOIA IN THE HEADON BEDS}

OF HORDWELL, HANTS.-While looking for seeds in the Leaf Bed of the Lower Headon series, Hordle (Hordwell), Hants, good specimens of Athrotaxis Couttsiae, so called by Starkie Gardner, have become available for study.

The material, which was in an uncrushed condition, yielded twigs and leaves, cones and cone-scales, and abundant seeds, and the discovery of one cone which still contained many seeds, and of another which was still attached to its twig, furnished indisputable evidence that the different organs found really belonged to one and the same species.

As the result of careful microscopic examination of leaves and stomata, of seeds, and of cones and cone-scales, the fossil can now be referred with confidence to the genus Sequoia.

Great interest was aroused by Starkie Gardner's reference of this Hordle fossil to the endemic Tasmanian genus Athrotaxis, for he stated that it was the same species as Sequoia Couttsiae, Heer, from the Hempstead Beds; at the same time he threw doubt upon other records of Sequoia from Eocene and Oligocene horizons.

Until I9IO no attempt was made to clear up the uncertainty thus occasioned, but in that year Mr. and Mrs. Clement Reid, after thorough investigation, confirmed Heer's determination of the Bovey Tracy species as Sequoia.

Now that material from Starkie Gardner's original locality for Athrotaxis has also proved to be Sequoia, it seems desirable to state the fact, pending a full account of the whole work for which there is not at present space.

\section{E. J. CHANDLER, \\ Late Harkness Scholar, Nerwnham Collese, Cambridge.}

PHLOEM NECROSIS (BROWN BAST DISEASE) IN HEVEA BRASILIENSIS. ${ }^{-}$- The disease known as brown bast is prevalent in all tropical countries where Hevea brasiliensis is grown on a large scale for commercial purposes, especially in plantations where tapping is in progress, and it is regarded at the present time as the most serious malady to which the Pará rubber tree is liable.

The external symptoms of brown bast are manifest in the form of longitudinal irregular cracks in the bark and nodular swellings (burrs), which are usually confined to the basal portions of the trunk and the larger lateral roots. The presence of

1 Farmer, J. B., and Horne, A. S. : On Brown Bast and its Immediate Cause. The India-rubber Journal, vol. lxi, No. 25 , June I8, 1921, p. 25.

[Annals of Botany, Vol. XXXV. No. CXXXIX. July, I92I.] 


\section{$2 \mathrm{BHL}$ Biodiversity Heritage Library}

Chandler, Marjorie Elizabeth Jane. 1921. "Note on the occurrence of sequoia in the headon beds of Hordwell, Hants." Annals of botany 35, 457-457. https://doi.org/10.1093/oxfordjournals.aob.a089767.

View This Item Online: https://www.biodiversitylibrary.org/item/235780

DOI: https://doi.org/10.1093/oxfordjournals.aob.a089767

Permalink: https://www.biodiversitylibrary.org/partpdf/319012

\section{Holding Institution}

Smithsonian Libraries

\section{Sponsored by}

Biodiversity Heritage Library

\section{Copyright \& Reuse}

Copyright Status: Not in copyright. The BHL knows of no copyright restrictions on this item.

This document was created from content at the Biodiversity Heritage Library, the world's largest open access digital library for biodiversity literature and archives. Visit BHL at https://www.biodiversitylibrary.org. 